\title{
TATA LAKSANA PENERIMAAN PERKARA
}

\author{
MAKALAH
}

Diajukan Untuk Memenuhi Tugas Mata Kuliah "Hukum Acara Peradilan Agama"

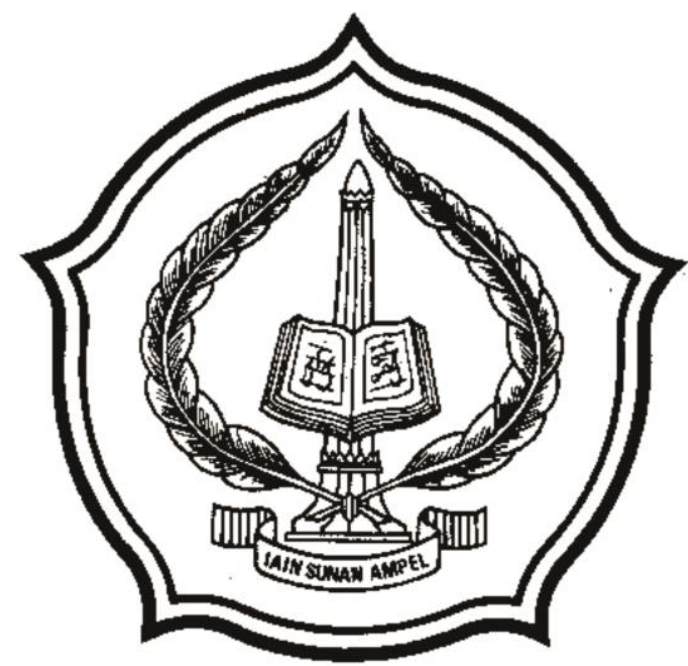

Disusun oleh:

$\begin{array}{ll}\text { Muhammad Rifqi Hidayat } & \text { C51208028 } \\ \text { Muhammad Yazid } & \text { C51208029 } \\ \text { Habib Luqman Hakim } & \text { C51208017 }\end{array}$

Dosen Pembimbing:

Dr. Iskandar Ritonga, M.Ag.

JURUSAN AHWAL AL SYAKHSHIYYAH

FAKULTAS SYARI'AH

INSTITUT AGAMA ISLAM NEGERI SUNAN AMPEL

SURABAYA 


\section{BAB I \\ PENDAHULUAN}

\section{A. Latar Belakang}

Untuk memulai dan menyelesaikan pemeriksaan persengketaan perkara perdata yang terjadi di antara anggota masyarakat, salah satu pihak yang bersengketa, harus mengajukan permintaan pemeriksaan kepada pengadilan. Apabila salah satu pihak mengajukan permintaan pemeriksaan, persengketaan menjelma menjadi "perkara" di sidang pengadilan. Selama sengketa tidak meminta pengadilan untuk menanganinya maka pengadilan tidak berhak ikut campur dalam mengadili dan pengadilan tidak bisa berbuat apa-apa.

Pengadilan berfungsi untuk memutuskan perkara-perkara yang diajukan kepadanya, dalam proses perkara tersebut terdapat prosedur yang harus dipenuhi oleh pihak pemohon atau penggugat sebagai pihak yang berperkara, dalam hal tersebut makalah ini akan memuat hal-hal yang terkait dengan prosedur pemohon atau penggugat dalam mengajukan perkara ke pengadilan agama khususnya.

\section{B. Rumusan Masalah}

Bagaimanakah proses penerimaan perkara di Pengadilan Agama?

\section{Tujuan Penulisan}

Memahami proses penerimaan perkara di Pengadilan Agama. 


\section{BAB II}

\section{PEMBAHASAN}

\section{A. Proses Perkara Perdata di Pengadilan Agama}

Proses administrasi perkara dipengadilan agama secara singkat adalah sebagai berikut:

1. Penggugat atau kuasanya datang ke bagian pendaftaran perkara di pengadilan agama, untuk menyatakan bahwa ia ingin mengajukan gugatan. Gugatan dapat diajukan dalam bentuk surat (tertulis), secara lisan, atau dengan kuasa yang ditunjukkan kepada ketua pengadilan agama dengan membawa surat bukti identitas diri yakni KTP;

2. Penggugat wajib membayar uang muka (voorschot) biaya atau ongkos perkara (pasal 121 ayat 4 HIR);

3. Panitera pendaftaran perkara menyampaikan gugatan kepada bagian perkara, sehingga gugatan secara resmi dapat diterima dan didaftarkan dalam buku regrister perkara.

4. Setelah didaftar, gugatan diteruskan kepada ketua pengadilan agama dan diberi catatan mengenai nomor, tanggal perkara dan ditentukan hari sidangnya;

5. Ketua pengadilan agama menentukan majelis hakim yang akan mengadili dan menentukan hari sidang;

6. Hakim ketua atau anggota majelis hakim (yang akan memeriksakan perkara) memeriksa kelengkapan surat gugatan;

7. Panitera memanggil penggugat dan tergugat dengan membawa surat panggilan sidang secara patut dan;

8. Semua pemeriksaan perkara dicatat dalam berita acara persidangan. ${ }^{1}$

\footnotetext{
${ }^{1}$ Sulaikin Lubis, Wismar 'Ain Marzuki, Gemala Dewi, Hukum Acara Perdata Peradilan Agama (Jakarta: Kencana Prenada Media Group, 2008) hal121-122.
} 
Kemudian secara rinci dapat diperjelas dengan hal-hal berikut:

Penggugat menghadap di meja 1:

1. Meja I:
a. Menerima surat gugatan dan salinannya.
b. Menaksir panjar bea perkara.
c. Membuat SKUM.

2. Kasir:
a. Menerima uang panjar dan membukukannya.
b. Menandatangani SKUM.
c. Member nomor pada SKUM dan tanda lunas.

3. Meja II
a. Mendaftar gugatan dalam register.
b. Member nomor perkara pada surat gugat sesuai nomor SKUM.
c. Menyerahkan kembali kepada penggugat satu helai surat gugat.
d. Mengatur berkas perkara dan menyerahkan kepada ketua melalui wakil panitera dan panitera.

4. Ketua PA
a. Mempelajari berkas.
b. Membuat PMH (Penetapan Majelis Hakim).

5. Panitera
a. Menunjuk panitera sidang.
b. Menyerahkan berkas kepada Majelis.

6. Majelis Hakim
a. Membuat PHS (Penetapan Hari Sidang) dan perintah memanggil para pihak oleh jurusita.
b. Menyidangkan perkara.

7. Memberitahukan kepada meja II dan kasir yang bertalian dengan tugas mereka.
a. Memutus perkara 
8. Meja III

a. Menerima berkas yang telah diminta dari Majelis Hakim.

b. Memberitahukan isi putusan kepada pihak yang tidak hadir lewat jurusita.

c. Memberitahukan kepada meja II dan kasir yang bertalian dengan tugas mereka.

d. Menetapkan kekuatan hukum.

9. Menyerahkan salinan kepada penggugat dan tergugat dan instansi terkait dan menyerahkan berkas yang telah dijahit kepada panitera muda hukum.

10. Panitera Muda Hukum
a. Mendata perkara.
b. Melaporkan perkara.
c. Mengarsipkan berkas perkara. ${ }^{2}$

\section{B. Pengajuan Perkara di Kepaniteraan}

Surat gugatan/permohonan yang telah dibuat dan ditandatangani diajukan ke kepaniteraan Pengadilan Agama. Surat gugatan diajukan pada sub kepaniteraan gugatan. Sedang permohonan pada sub kepaniteraan permohonan, penggugat/pemohon menghadap pada meja pertama yang akan menaksir besarnya panjar biaya perkara dan menulisnya pada Surat Kuasa Untuk Membayar (SKUM).

Besarnya panjar biaya perkara diperkirakan harus telah mencukupi untuk menyelesaikan perkara tersebut.

\section{Catatan :}

1. Bagi yang tidak mampu dapat diijinkan berperkara secara prodeo (cumacuma). Ketidakmampuan tersebut dibuktikan dengan melampirkan surat keterangan dari Lurah atau Kepala Desa setempat yang dilegalisasi oleh Camat.

\footnotetext{
${ }^{2}$ Mukti Arto, Praktek Perkara Perdata pada Pengadilan Agama, (Yogyakarta: Pustaka Pelajar, 2011), hal 58-59.
} 
2. Bagi yang tidak mampu maka panjar biaya perkara ditaksir Rp. 0,00 dan ditulis dalam Surat Kuasa Untuk Membayar (SKUM), didasarkan pasal $237-245$ HIR.

3. Dalam tingkat pertama, para pihak yang tidak mampu atau berperkara secara prodeo. Perkara secara prodeo ini ditulis dalam surat gugatan atau permohonan bersama-sama (menjadi satu) dengan gugatan perkara. Dalam posita surat gugatan atau permohonan disebutkan alasan penggugat atau pemohon untuk berperkara secara prodeo dan dalam petitumnya. $^{3}$

\section{Pembayaran Panjar Biaya Perkara}

Calon penggugat/pemohon kemudian menghadap kepada kasir dengan menyerahkan surat gugat/permohonan tersebut dan SKUM. Ia membayar panjar biaya perkara sesuai dengan yang tertera pada SKUM tersebut.

Kasir kemudian:

1. Menerima uang tersebut dan mencatat dalam jurnal biaya perkara.

2. Menandatangani dan memberi nomor perkara serta tanda lunas pada SKUM tersebut.

3. Mengembalikan surat gugat/permohonan dan SKUM kepada calon penggugat/pemohon.

4. Menyerahkan uang panjar tersebut kepada bendaharawan perkara.

Catatan: nomor perkara dibuat 4 lajur dengan tanda $\mathrm{P}$ untuk perkara permohonan dan $\mathrm{G}$ untuk perkara gugatan.

Contoh panjar biaya perkara pada Pengadilan Agama yang dikutip dari PA Pontianak untuk radius i meliputi wilayah kecamatan Pontianak Tenggara:

\section{$\underline{\text { Perkara Cerai Talak }}$}

1. Biaya Pendaftaran = Rp. 30.000,-

2. Biaya ATK Perkara = Rp. 50.000,-

3. Biaya Redaksi = Rp. 5.000,-

4. Biaya Materai = Rp. 6.000,-

\footnotetext{
${ }^{3}$ http://pn-yogyakota.go.id/pnyk/profil/profil-pegawai/kepaniteraan-hukum/23-pengajuan-perkara.html
} 
5. Biaya Panggilan / Pemberitahuan:
a. Pemohon : 3 x Rp. 50.000,-
Rp. $150.000,-$
b. Termohon : 4 x Rp. 50.000,-
Rp. 200.000,-

Jumlah Rp. 441.000,-

\section{$\underline{\text { Perkara Cerai Gugat }}$}

1. Biaya Pendaftaran

$=$ Rp. 30.000,-

2. Biaya ATK Perkara

$=$ Rp. 50.000,-

3. Biaya Redaksi

$=$ Rp. 5.000,-

4. Biaya Meterai

$=$ Rp. $\quad 6.000,-$

5. Biaya Panggilan / Pemberitahuan:
a. Pemohon : $2 \times$ Rp. 50.000,-
= Rp. 100.000,-
b. Termohon : 3 x Rp. 50.000,- = Rp. 150.000,-

Jumlah = Rp. 341.000,-

Perkara Lainnya (Permohonan/Gugatan)
1. Biaya Pendaftaran
$=$ Rp. 30.000,-
2. Biaya ATK Perkara
$=$ Rp. 50.000,-
3. Biaya Redaksi
$=$ Rp. $5.000,-$
4. Biaya Meterai
$=$ Rp. $\quad 6.000,-$

5. Biaya Panggilan / Pemberitahuan

a. Pemohon : 2 x 60.000,- x Jlh Pihak, Tergantung banyaknya jumlah pihak

b. Termohon : 3 x 60.000,- x Jlh Pihak

Jumlah

$$
=\text { relatif }
$$

\section{Pendaftaran Perkara}

Calon penggugat/pemohon kemudian menghadap pada meja II dengan menyerahkan surat gugatan/permohonan dan SKUM (surat kuasa untuk membayar) yang dibayar tersebut. 
Kemudian meja II:

1. Memberi nomor pada surat gugatan/permohonan sesuai dengan nomor yang diberikan oleh kasir. Sebagai tanda telah terdaftar maka petugas meja kedua membubuhkan paraf.

2. Menyerahkan satu lembar surat gugatan/permohonan yang telah terdaftar bersama satu helai SKUM kepada penggugat/pemohon.

3. Mencatat surat gugatan/permohonan tersebut pada buku register induk perkara permohonan atau register induk perkara gugatan sesuai dengan jenis perkaranya.

4. Memasukkan surat gugatan atau permohonan tesebut dalam map berkas perkara dan menyerahkan kepada wakil panitera untuk disampaikan kepada ketua pengadilan melalui panitera. ${ }^{4}$

\section{E. Penetapan Majelis Hakim}

Setelah perkara terdaftar di kepaniteraan Pengadilan Agama, Panitera wajib secepatnya menyampaikan berkas perkara itu kepada Ketua Pengadilan Agama, disertai "usul tindak" atau "saran tindak" yang kira-kira berbunyi " sudah diteliti dan syarat formal cukup". Atas dasar itu, Ketua Pengadilan Agama dapat menunjuk Majelis Hakim yang akan memeriksa dan mengadili perkara tersebut, dengan surat penetapan, disebut "Penunjukkan Majelis Hakim"(PMH). ${ }^{5}$

Dalam waktu selambat-lambatnya 7 (tujuh) hari, Ketua menunjuk Majelis Hakim untuk memeriksa dan mengadili perkara dalam sebuah Penetapan Majelis Hakim (pasal 121 HIR jo pasal 93 UU-PA). Ketua membagikan semua berkas perkara dan atau surat-surat yang berhubungan dengan perkara yang diajukan ke Pengadilan pada Majelis Hakim untuk diselesaikan.

Ketua menetapkan perkara yang harus diadili berdasarkan nomor urut, tetapi apabila terdapat perkara tertentu karena menyangkut kepentingan umum harus segera diadili, maka perkara itu didahulukan (pasal 94 UU-PA). Penunjukkan Majelis Hakim (PMH) dibuat dalam bentuk "penetapan" dan ditandatangani oleh ketua PA dan dicatat dalam register induk perkara yang bersangkutan.

\footnotetext{
${ }^{4}$ Mukti Arto, Praktek Perkara Perdata Pada Pengadilan Agama, hal 61.

${ }^{5}$ Roihan Rasyid, Hukum Acara Peradilan Agama (Jakarta: PT. Raja Grafindo Persada, 2010) hal 80.
} 


\section{F. Penunjukkan Panitera Sidang}

Untuk membantu majelis hakim dalam menyelesaikan perkara ditunjuk seorang atau lebih panitera sidang (pasal 15 ayat (4) UU No.14/1970). Penunjukkan panitera sidang dilakukan oleh panitera (pasal 96 UU-PA). Untuk menjadi panitera sidang dapat ditunjuk panitera, wakil panitera, panitera muda, panitera pengganti atau pegawai yang ditugaskan sebagai panitera sidang untuk membantu hakim supaya menghadiri dan mencatat jalannya sidang pengadilan, membuat berita acara persidangan, penetapan, putusan dan pelaksanaan semua pemerintah hakim untuk menyeleseikan perkara tersebut (pasal 97 UU-PA). Penunjukkan PPS dibuat secara tertulis dan ditandatangani oleh panitera PA.

Apabila ternyata di kemudian hari, anggota majelis hakim ada yang berhalangan untuk sementara, maka dapat diganti dengan anggota lain yang ditunjuk oleh ketua dan dicatat dalam BAP. Apabila Ketua Majelis berhalangan maka sidang harus ditunda pada hari lain. Tetapi apabila Ketua Majelis atau anggota majelis berhalangan tetap (karena pindah tugas atau meninggal dunia atau urusan lain) maka harus ditunjuk Majelis baru dengan PMH baru.

Apabila panitera sidang berhalangan maka ditunjuk panitera lainnya untuk mengikuti sidang. ${ }^{6}$

\section{G. Penetapan Hari Sidang}

Selepas Ketua Majelis menerima berkas perkara dan mempelajari berkas tersebut bersama kedua hakim anggotanya, maka Ketua Majelis kemudian menetapkan hari, tanggal, dan jam diadakannya persidangan atas perkara tersebut yang kemudian dituangkan dalam sebuah Penetapan Hari Sidang (PHS) yang ditandatangani Ketua Majelis Hakim.

Dalam menetapkan hari sidang ini, majelis hakim harus mempertimbangkan beberapa hal, yaitu:

1. Jarak antara hari sidang pertama tidak lebih dari 30 hari sejak tanggal didaftarkannya perkara tersebut, kecuali Undang-Undang menentukan lain.

2. Domisili atau tempat tinggal kedua belah pihak dengan tempat Pengadilan Agama melakukan persidangan.

\footnotetext{
${ }^{6}$ Mukti Arto, Praktek Perkara Perdata Pada Pengadilan Agama, hal 62.
} 
3. Tenggang waktu antara hari diterimanya pemanggilan dengan hari sidang tidak kurang dari 3 hari kerja.

Selanjutnya Majelis memerintahkan pemanggilan kepada para pihak yang berperkara. Perintah tersebut berbentuk formulir PGL 1 dan 2 yang diisi sesuai dengan PHS-nya yang ditandatangani Ketua Majelis Hakim. ${ }^{7}$

\section{H. Pemanggilan}

Setelah dikeluarkannya penetapan mengenai hari, tanggal, dan jam dilaksanakannya sidang oleh Majelis Hakim, maka Jurusita selaku petugas yang bertanggung jawab untuk melaksanakannya kemudian melakukan pemanggilan kepada para pihak yang berperkara. Pemanggilan disampaikan dalam bentuk Surat Panggilan (Relaas) kepada pihak-pihak yang berperkara. ${ }^{8}$

Di dalam Relaas harus dilampirkan pula salinan surat gugatan/permohonan kepada tergugat/termohon. Selain itu juga Surat Panggilan juga harus menyebutkan bahwa tergugat/termohon boleh mengajukan jawaban tertulis dan bahwa para pihak diperbolehkan membawa bukti-bukti ataupun saksi-saksi yang diperlukan dalam persidangan. ${ }^{9}$

Pemanggilan hanya dianggap sah apabila dilakukan dengan benar dan patut sesuai dengan aturan yang berlaku. Jika tidak dilakukan dengan benar, maka pihak yang dipanggil berhak untuk tidak menghadiri sidang tanpa terkena resiko verstek atas ketidakhadiran dirinya.

Keabsahan dan kepatutan pemanggilan tersebut dianggap sudah terpenuhi apabila:

1. Dilakukan oleh Jurusita atau Jurusita pengganti yang sah, yang telah diangkat dengan SK dan disumpah untuk jabatannya itu.

2. Disampaikan langsung kepada pihak yang berperkara. Dalam hal ini terdapat beberapa pengecualian berdasarkan domisili dan kondisi tergugat/termohon, yaitu sebagai berikut:

\footnotetext{
${ }^{7}$ Ibid, hal 62.

${ }^{8}$ Abdul Manan, Penerapan Hukum Acara Perdata di Lingkungan Peradilan Agama (Jakarta: Kencana, 2008) hal 135.

${ }^{9}$ Mukti Arto, Praktek Perkara Perdata Pada Pengadilan Agama, hal 66.
} 
a. Jika tergugat/termohon berada di luar wilayah yuridiksi pengadilan agama maka Ketua Pengadilan Agama memohon bantuan kepada Pengadilan Agama yang berada di wilayah yuridiksi pihak tersebut untuk melakukan pemanggilan. Permohonan itu dituangkan dalam sebuah Surat Permohonan yang bersamanya dilampirkan salinan Surat Gugatan. Selanjutnya, pemanggilan akan dilakukan oleh Jurusita dari Pengadilan Agama yang dimintakan bantuannya itu.

b. Jika tergugat/termohon tidak dijumpai di tempat tinggalnya, maka Surat Panggilan dititipkan kepada kepala desa atau lurah setempat.

c. Jika tergugat/termohon berada di luar negeri, maka pemanggilan dilakukan melalui Departemen Luar Negeri yang kemudian disampaikan ke Kedutaan Besar RI di negara tersebut. ${ }^{10}$

d. Jika tergugat/termohon tidak diketahui tempat tinggalnya, maka pemanggilan dilakukan melalui media massa.

e. Jika tergugat/termohon telah meninggal, maka pemanggilan diberikan kepada ahli warisnya. Hal ini biasanya terjadi dalam kasus kewarisan.

Adapun untuk pihak penggugat/pemohon biasanya hal ini tidak menjadi masalah karena sudah tentu alamatnya jelas dan berada di wilayah yuridiksi Pengadilan Agama tempat ia mendatarkan perkaranya sehingga sangat mudah bagi Jurusita untuk melakukan pemanggilan. Namun jika ia tidak dijumpai di tempat tinggalnya maka Surat Panggilan dititipkan kepada Kepala Desa atau Lurah setempat.

Mengenai pemanggilan lewat media massa ada beberapa ketentuan yang harus ditaati, yaitu:

a. Pengumuman dilakukan sebanyak dua kali.

b. Jarak antara kedua pengumuman tersebut adalah 1 bulan.

c. Jarak antara pengumuman kedua dan hari persidangan minimal 3 bulan.

d. Jika tergugat/termohon datang ke pengadilan agama sebelum hari persidangan dan menyampaikan alamatnya saat ini, maka

\footnotetext{
${ }^{10}$ Andi Tahir Hamid, Beberapa Hal Baru Tentang Peradilan Agama dan Bidangnya (Jakarta: Sinar Grafika, 1996) hal 116.
} 
penggugat/pemohon diharuskan memperbaiki surat gugatan/permohonannya. Kemudian Majelis Hakim membatalkan PHS lama dan menetapkan PHS dan Relaas baru berdasarkan alamat baru tersebut. ${ }^{11}$

3. Jarak antara hari diterimanya Surat Panggilan dan hari persidangan harus memenuhi tenggang waktu yang patut minimal 3 hari kerja. Dalam hal ini pun terdapat sedikit pengecualian apabila para pihak berada di luar negeri, yaitu bahwa jangka waktu antara pemanggilan dan hari sidang tersebut idealnya minimal 3 bulan dan maksimal 6 bulan. ${ }^{12}$ 


\section{BAB III}

\section{PENUTUP}

\section{A. Kesimpulan}

Tata cara penerimaan perkara di Pengadilan Agama adalah sebagai berikut:

1. Pemohon/Penggugat mengajukan perkara di kepaniteraan Pengadilan Agama di meja pertama yang akan menaksir biaya panjar bagi perkara tersebut.

2. Kemudian pemohon/penggugat tersebut pergi kepada kasir untuk membayar biaya perkara. Jika ia seorang yang tidak mampu, maka boleh memohon persidangan secara prodeo dengan membawa Surat Keterangan Tidak Mampu dari Lurah atau Kepala Desa setempat yang dilegalisasi oleh Camat.

3. Setelah membayar panjar, tergugat/termohon kemudian maju ke meja II dengan membawa surat gugatan/permohonannya beserta SKUM untuk diberi nomor perkara dan dicatatkan dalam Register Induk Perkara.

4. Selepas perkara terdaftar di kepaniteraan, panitera segera menyampaikan perkara tersebut kepada Ketua Pengadilan yang kemudian Ketua itu menunjuk Majelis Hakim untuk persidangan tersebut

5. Ditunjuk Panitera Sidang untuk membantu Majelis Hakim dalam persidangan tersebut

6. Setelah Majelis Hakim mempelajari berkas-berkas perkara maka mereka membuat Penetapan Hari Sidang yang berisi tanggal dan jam sidang.

7. Setelah dikeluarkannya PMH, dilakukan pemanggilan oleh Jurusita kepada para pihak yang berperkara. Teknis pemanggilan tersebut dianggap sah apabila dilaksanakan secara resmi dan patut sesuai peraturan yang berlaku.

\section{B. Saran dan Kritik}

Demikian makalah tentang tata laksana penerimaan perkara dan berbagai hal yang berhubungan dengannya. Kami sebagai penulis menyadari bahwa di makalah ini terdapat banyak kekurangan. Besar harapan kami agar dosen maupun sahabat memberikan saran dan kritik yang bersifat membangun untuk kemajuan ilmu pengetahuan kita bersama. 


\section{DAFTAR PUSTAKA}

Abdul Manan, 2008, Penerapan Hukum Acara Perdata di Lingkungan Peradilan Agama Kencana, Jakarta.

Andi Tahir Hamid, 1996, Beberapa Hal Baru Tentang Peradilan Agama dan Bidangnya Sinar Grafika, Jakarta.

http://pn-yogyakota.go.id/

Mukti Arto, 2011, Praktek Perkara Perdata pada Pengadilan Agama, Pustaka Pelajar, Yogyakarta.

Roihan Rasyid, 2010, Hukum Acara Peradilan Agama, PT. Raja Grafindo Persada, Jakarta.

Sulaikin Lubis, Wismar 'Ain Marzuki, Gemala Dewi, 2008, Hukum Acara Perdata Peradilan Agama, Kencana Prenada Media Group, Jakarta. 